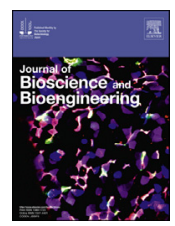

\title{
Protection of Lactobacillus acidophilus NRRL-B 4495 under in vitro gastrointestinal conditions with whey protein/pullulan microcapsules
}

\author{
Burcu Çabuk and Şebnem Tellioğlu Harsa
}

\begin{abstract}
Department of Food Engineering, Faculty of Engineering, Izmir Institute of Technology, 35430 Gülbahçe Köyü, Urla, Izmir, Turkey
\end{abstract}
Received 3 March 2015; accepted 20 April 2015

Available online 19 June 2015

In this research, whey protein/pullulan (WP/pullulan) microcapsules were developed in order to assess its protective effect on the viability of Lactobacillus acidophilus NRRL-B 4495 under in vitro gastrointestinal conditions. Results demonstrated that WP/pullulan microencapsulated cells exhibited significantly $(p \leq 0.05)$ higher resistance to simulated gastric acid and bile salt. Pullulan incorporation into protein wall matrix resulted in improved survival as compared to free cells after $3 \mathrm{~h}$ incubation in simulated gastric solution. Moreover WP/pullulan microcapsules were found to release over 70\% of encapsulated $L$. acidophilus NRRL-B 4495 cells within $1 \mathrm{~h}$. The effect of encapsulation during refrigerated storage was also studied. Free bacteria exhibited $3.96 \mathrm{log}$ reduction while, WP/pullulan encapsulated bacteria showed $1.64 \log$ reduction after 4 weeks of storage.

() 2015, The Society for Biotechnology, Japan. All rights reserved.

[Key words: Encapsulation; Pullulan; Whey protein; Lactobacillus acidophilus; Probiotic]

Viability losses during storage and gastrointestinal transit due to detrimental conditions such as harsh acidic environment, oxygen stress and enzymatic reactions reduce the functionality of probiotics to exert health benefits (1,2). Thus, microencapsulation of probiotics is considered as an effective approach for their efficient survival under gastrointestinal conditions and to improve the viability during shelf life to maintain their health promoting effects.

Additionally, mechanical protection of probiotic cells during incorporation process into food product is another advantage of microencapsulation $(3,4)$. Despite wide applications of several microencapsulation materials for probiotics, it is a challenge to produce microcapsules for preservation of desired bacterial culture with high viability which does not cause non desirable texture in the final product. Proteins and polysaccharides are widely used materials for the microencapsulation of bioactive ingredients (5-8). Whey protein is one of the most widely used polymer for microencapsulation processes. It is proved to be an effective encapsulating agent in microencapsulation of bioactive ingredients because of their ability to form microcapsules easily under mild conditions using different techniques $(9,10)$.

Pullulan is an extracellular polysaccharide produced by Aureobasidium pullulans. It is especially used as a coating material in the food industry, paper industry and pharmaceutical area because of its non-toxic, water-soluble, colorless, tasteless, odorless and heat stable characteristics. Many different industrial wastes such as potato peel, grape skin and olive oil wastes found to be used as a carbon source for the synthesis of pullulan $(11,12)$. More recently, combination of proteins, especially whey proteins, with

\footnotetext{
* Corresponding author. Tel.: +90 232750 6291; fax: +90 2327506196 .

E-mail addresses: burcucabuk@iyte.edu.tr (B. Cabuk), sebnemharsa@iyte.edu.tr (Ş. Tellioğlu Harsa).
}

polysaccharides has been studied for microencapsulation of bioactive substances. Whey protein and pullulan mixtures have been studied to form edible films to reduce moisture loss and increase the shelf life in food applications $(13,14)$.

The present study aimed at microencapsulation of probiotic Lactobacillus acidophilus NRRL-B 4495 within whey protein/pullulan biopolymer blend and evaluating the survivability of encapsulated cells under in vitro gastrointestinal conditions. We also attempted to examine protective effect of polymer matrix during storage.

\section{MATERIALS AND METHODS}

Materials Commercial strain of L. acidophilus NRRL-B 4495 was obtained from the ARS Culture Collection (NRRL, USA). Ox-bile and de Man, Rogosa and Sharpe (MRS) media were purchased from Fluka (Buchs, Switzerland). Trypsin (from bovine) was purchased from Merck (Darmstadt, Germany) and pepsin (from porcine stomach mucosa) from Sigma (St. Louis, MO, USA). Sunflower oil was obtained from a local store. Pullulan was a gift from Hayashibara Co. (Japan) Whey protein isolate (WP) was obtained from BiPro, Danisco. All other chemicals were obtained from Sigma.

Bacterial strain and culture preparations L. acidophilus NRRL-B 4495 cells were inoculated into $5 \mathrm{ml}$ of MRS broth in $0.1 \%$ ratio and incubated at $37^{\circ} \mathrm{C}$ for $24 \mathrm{~h}$ under anaerobic conditions. The cultures were then subcultured into $20 \mathrm{ml}$ of MRS broth and incubated under same conditions for $12 \mathrm{~h}$. The cells were harvested by centrifugation at $15,000 \mathrm{rpm}$ for $10 \mathrm{~min}$ at $4^{\circ} \mathrm{C}$ from $20 \mathrm{ml}$ of a $12 \mathrm{~h}$ culture at the initial stationary phase. The supernatant was decanted, and the cells were resuspended in $100 \mathrm{ml}$ of pullulan-WP solution obtaining a cell load of about $9.0 \mathrm{log}$ CFU ml $\mathrm{ml}^{-1}$.

Formation of $\mathbf{W P} /$ pullulan wall matrix Whey protein isolate-pullulan microcapsules were prepared according to the method of Wood (15) with some modifications. Briefly, whey protein isolate (WP, $9 \% \mathrm{w} / \mathrm{v}$ ) was dispersed by mixing the protein powder in sterile distilled water at ambient temperature. Protein solution was then stirred for approximately $3 \mathrm{~h}$ using a magnetic stirrer to ensure proper dissolution under $4^{\circ} \mathrm{C}$ and after hydration, protein solution was denatured 
at $80^{\circ} \mathrm{C}$ for $30 \mathrm{~min}$. Denatured protein solution was cooled to room temperature in ice bath.

Pullulan were dissolved in distilled water at ambient temperature and stirred for approximately $3 \mathrm{~h}$ using a magnetic stirrer to ensure proper dissolution. In order to form WP/pullulan polymer blend as a wall material, pullulan solution was then sterilized by $0.45 \mu \mathrm{m}$ filter and mixed with the denatured WP solution $(9.0 \%, \mathrm{w} / \mathrm{v})$ at a final concentration of $2.0 \%(\mathrm{w} / \mathrm{v})$.

Preparation of microcapsules Microcapsules were prepared by emulsification/cold gelation technique performed as described by Chen and Subirade (16) with some modifications. In the first step, primary water-in-oil emulsions $\left(W_{1} / 0\right)$ were formed by emulsifying an inner aqueous phase $\left(\mathrm{W}_{1}\right)$ made up by WP/ pullulan polymer blend containing bacteria into an oil phase $(\mathrm{O})$ containing $1 \%$ Polyglycerol polyricinoleate (PGPR) as an emulsifier. $\mathrm{W}_{1} / \mathrm{O}$ emulsion was prepared by an Ultra Turrax homogenizer (Ultra Turrax, model T25, IKA Labortechnik, Staufen, Germany) at $3000 \mathrm{rpm}$ for $15 \mathrm{~min}$. This emulsion was then added with gentle mixing to $\mathrm{CaCl}_{2}$ solution $(100 \mathrm{mM})$. After formation of microcapsules, this slurry was orbitally shaked at $160 \mathrm{rpm}$ for $30 \mathrm{~min}$ to harden the microcapsules. The hardened microcapsules were separated from the solution and oil phase by two sets of homogenization at $1000 \mathrm{rpm}$ for $1 \mathrm{~h}$. It is important to state that in order to avoid the destructive heat generation possibly formed during homogenization; microencapsulation process was conducted inside the ice bath.

Bacterial enumeration Viable counts of non-encapsulated $L$. acidophilus NRRL-B 4495 were determined by a pour plate method using MRS agar after serial dilutions in peptone water. The plates were incubated anaerobically at $37^{\circ} \mathrm{C}$ for $72 \mathrm{~h}$ and colony forming units were counted.

For enumeration of microencapsulated bacteria in microcapsules, $10 \mathrm{~g}$ of microcapsules were suspended in peptone water. This peptone water containing microcapsules was homogenized at $11,000 \mathrm{rpm}$ for $5 \mathrm{~min}$. Under these conditions, microcapsules were broken and samples of $1 \mathrm{ml}$ of the peptone water were diluted to an appropriate dilution and plated by the pour plate technique using MRS agar. Colonies were counted after $72 \mathrm{~h}$ of anaerobic incubation at $37^{\circ} \mathrm{C}$. Viable cell number was express as CFU per gram of microcapsule ( $\mathrm{CFU} / \mathrm{g}$ ) and the efficiency was determined as following Eq. 1:

$$
\text { Encapsulation yield }(\%)=100 \times\left(\mathrm{N} / \mathrm{N}_{0}\right)
$$

where $\mathrm{N}$ is the total viable count of L. acidophilus after microencapsulation and $\mathrm{N}_{0}$ is the total viable count of $L$. acidophilus before microencapsulation.

Survival in simulated gastrointestinal conditions Simulated gastric juice (SGJ) was prepared according to the method described by Guo et al. (17) with some modifications. Saline solution $(0.85 \%) \mathrm{pH}$ was adjusted to 2.0 using $0.1 \mathrm{~N} \mathrm{HCl}$ and sterilized by autoclaving at $121^{\circ} \mathrm{C}$ for $15 \mathrm{~min}$. Pepsin was dissolved in sterile deionized water and filtered through $0.22 \mu \mathrm{m}$ sterile membrane filter, then suspended in sterile saline to a final concentration of $3.0 \mathrm{~g} / \mathrm{L}$. To prepare bile salt solution, MRS media was supplemented with $0.6 \%$ ox-bile (18).

For resistance in simulated gastrointestinal conditions, $1.0 \mathrm{ml}$ of free or $1.0 \mathrm{~g}$ of microencapsulated L. acidophilus NRRL-B 4495 cells were inoculated into $9.0 \mathrm{ml}$ of sterile SGJ/bile salt solution and incubated at $37^{\circ} \mathrm{C}$ under orbital shaking at $160 \mathrm{rpm}$ for $3 \mathrm{~h} / 24 \mathrm{~h}$. After the incubation, samples were removed from solutions and survival rate (\%) was calculated by Eq. 2.

$$
\text { Survival rate } \%=\left(\log \text { CFU N } 1 / \log C F U N_{0}\right) \times 100 \%
$$

where $N_{1}$ is the is the number of viable cells in microcapsules after treatment by SGJ/ bile salt solution and $\mathrm{N}_{0}$ is the is the number of viable cells in microcapsules before treatment.

Release into simulated intestinal juice Saline solution $(0.85 \%) \mathrm{pH}$ was adjusted to the 8.0 using $0.5 \mathrm{M} \mathrm{NaOH}$ and sterilized by autoclaving at $121^{\circ} \mathrm{C}$ for 15 min. Trypsin was dissolved in sterile deionized water and filtered through $0.45 \mu \mathrm{m}$ sterile membrane filter, then suspended in sterile saline solution to a final concentration of $1 \mathrm{~g} / \mathrm{L}(17) .1 .0 \mathrm{~g}$ of microencapsulated bacteria were transferred into the $9.0 \mathrm{ml}$ of simulated intestinal juice and incubated at $37^{\circ} \mathrm{C}$ under orbital shaking at $160 \mathrm{rpm}$ for $24 \mathrm{~h}$. After the incubation, samples were taken from supernatant and viable bacteria released in SIJ were enumerated. Released rate (\%) was calculated according to Eq. 3:

$$
\text { Release rate } \%=\left(\log \mathrm{CFU} \mathrm{N} \mathrm{N}_{1} / \log \mathrm{CFU} \mathrm{N}\right)_{0} \times 100 \%
$$

where $\mathrm{N}_{1}$ is the number of viable cells released from microcapsules in SIJ and $\mathrm{N}_{0}$ is the number of viable cells in microcapsules added to SIJ.

Morphology and particle diameter distribution of microcapsules The morphology of microcapsules was examined by scanning electron microscopy (SEM). Prior to SEM, microcapsules were freeze dried and then placed on strips of double side carbon tape attached to aluminum SEM stubs and photographs were taken under low vacuum using an electron acceleration voltage of $10.0 \mathrm{kv}$ with SEM (Quanta 250, FEI).

For light microscopy images, $1.0 \mathrm{~g}$ of microcapsules was placed on a glass microscope slide with a cover slide. Microscopic pictures were taken using an Olympus CX31 Microscope, fitted with an Olympus DP25 Camera and diameter analysis was done with software (Olympus DP2-BSW).
TABLE 1. Encapsulation efficiency and particle mean diameter of WP and WP/pullulan microcapsules loaded with L. acidophilus NRRL-B 4495.

\begin{tabular}{lccc}
\hline & $\begin{array}{c}\text { Microbial load } \\
(\log \text { CFU/g) }\end{array}$ & $\begin{array}{c}\text { Encapsulation } \\
\text { efficiency }(\%)\end{array}$ & $\begin{array}{c}\text { Mean particle } \\
\text { size }(\mu \mathrm{m})\end{array}$ \\
\hline WP microcapsules & $9.20 \pm 0.18$ & $93.57 \pm 0.21$ & $65.12 \pm 1.12^{\mathrm{a}}$ \\
$\begin{array}{l}\text { WP/pullulan } \\
\quad \text { microcapsules }\end{array}$ & $9.33 \pm 0.21$ & $93.72 \pm 0.10$ & $76.40 \pm 1.54^{\mathrm{b}}$ \\
\hline
\end{tabular}

${ }^{\mathrm{a}, \mathrm{b}}$ Means \pm standard deviation $(\mathrm{n}=3$ ) with different superscript letters in the same column indicate significant differences $(p \leq 0.05)$ among the studied samples.

Color measurement Konica Minolta colorimeter (model CR 410, Konica Minolta, Tokyo, Japan) was used for color measurements of microcapsules. The CIE Lab system, defined in rectangular coordinates $L^{*}, a^{*}, b^{*}$, where $L^{*}$ represents lightness, $\mathrm{a}^{*}$ represents red-green and $\mathrm{b}^{*}$ represents yellow-blue.

Moisture content and water activity Water activity of the microcapsules was determined using a Hygrolab C1 water activity meter (Hygrolab C1, Rotronic, Bassersdorf, Switzerland) (19). The moisture content of the microcapsules was determined gravimetrically by oven-drying at $105^{\circ} \mathrm{C}$ for $24 \mathrm{~h}$ to reach weight equilibrium (20). The mean moisture content (MC) was estimated by the following Eq. 4:

$$
\operatorname{MC}(\%)=\left[\left(\mathrm{W}_{\text {wet }}-\mathrm{W}_{\text {dry }}\right) / \mathrm{W}_{\text {wet }}\right] * 100
$$

where $\mathrm{W}_{\text {wet }}$ is the weight of the wet microcapsules and $\mathrm{W}_{\text {dry }}$ is the weight of fully dry microcapsules.

Storage stability test In order to examine the storage stability, both free bacteria and the microcapsules were placed at $4{ }^{\circ} \mathrm{C}$ in glass bottles for 4 weeks with compressed $\mathrm{N}_{2}$ for 4 weeks. The number of viable cell counts was determined weekly and all the samples were analyzed in triplicate.

Statistical analysis Experiments were performed with three different batches of drying, and each batch was tested in triplicate. Results were expressed as means \pm standard deviation. Data analysis was carried out using Minitab 14.0 software (Minitab Inc., State College, PA, USA). Significance of differences between formulations was performed by analysis of variance (ANOVA) test followed by Tukey's test (95\% confidence interval).

\section{RESULTS AND DISCUSSION}

Microencapsulation Table 1 shows that existence of pullulan resulted in a bigger mean diameter size of microcapsules providing to a microcapsule size of $76.40 \mu \mathrm{m}$, whereas WP microcapsules obtained mean particle size of $65.12 \mu \mathrm{m}$. This can be attributed to the increased polymer concentration of wall matrix due to pullulan incorporation. By the increase in polymer concentration, the viscosity of the inner phase of the primary emulsion might be increased causing resistance to break into smaller droplets and resulting in larger microcapsule sizes (21-24). Besides, increased particle mean diameter, results revealed that no significant $(p>0.05)$ difference was calculated between encapsulation efficiencies of pullulan containing and non pullulan containing microcapsules. Encapsulation efficiency is one of the most important parameter indicating the effect of encapsulation process and selected wall matrix. Cell loading achieved with WP/ pullulan was calculated to be $93.72 \%$, while microencapsulation efficiency of $93.57 \%$ was achieved with WP microcapsules. The average count of $L$. acidophilus NRRL-B 4495 in WP/pullulan microcapsules was $9.33 \pm 0.21 \log \mathrm{CFU} / \mathrm{g}$.

Survival under simulated gastric juice and simulated bile salt solution One of the main objectives of microencapsulation is providing protection of probiotic cells during exposure to low $\mathrm{pH}$ gastric environment. Fig. $1 \mathrm{~A}$ shows the number of survived cell counts of free and microencapsulated L. acidophilus NRRL B-4495 under simulated gastric juice. After an hour of incubation, L. acidophilus NRRL B-4495 was reduced by $0.95 \log$ units when added as free cells and followed nearly a linear reduction in cell numbers. At the end of incubation, viable cell numbers of free cells decreased to $6.67 \mathrm{log} \mathrm{CFU} / \mathrm{ml}$ possessing the survival rate of 73.19\%. On the other hand, microencapsulation into WP and WP/ 
A

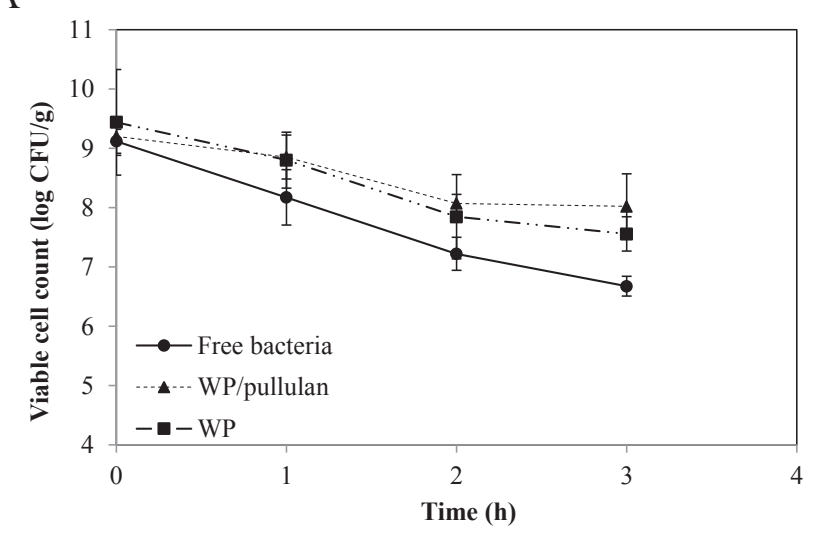

B

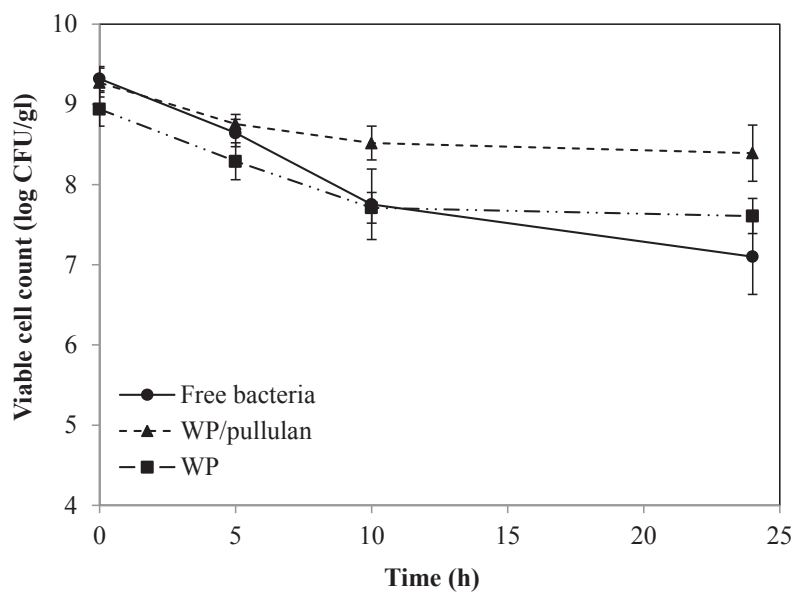

FIG. 1. Survived cell counts of free (circles) and encapsulated Lactobacillus acidophilus NRRL B-4495 in WP (squares) and WP/pullulan (triangles) after exposure to (A) simulated gastric juice at $37^{\circ} \mathrm{C}$ at $\mathrm{pH} 3.0$ and (B) simulated bile salt solution at $37^{\circ} \mathrm{C}$. Values shown are means \pm standard deviations $(n=3)$.

pullulan microcapsules offered significant $(p \leq 0.05)$ protection throughout the incubation time. Moreover, results indicated that bacterial cells were better protected in the presence of pullulan in wall material after $3 \mathrm{~h}$ exposure to low $\mathrm{pH}$; WP/pullulan

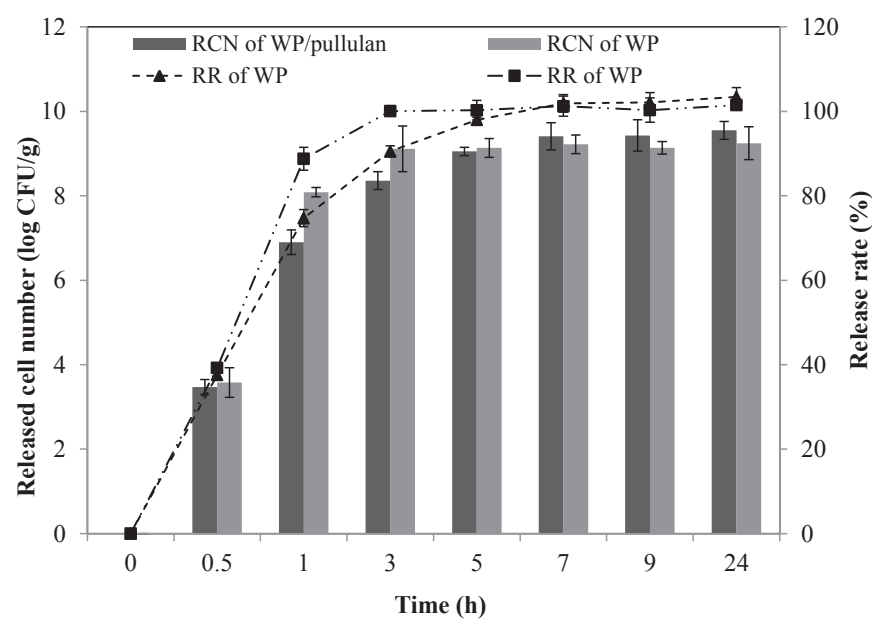

FIG. 2. Released cell counts (RCN) and release rates (RR) of encapsulated Lactobacillus acidophilus NRRL B-4495 in WP (squares) and WP/pullulan (triangles) in simulated intestinal juice $(\mathrm{pH} \mathrm{8.0)}$ ) after $3 \mathrm{~h}$ exposure to $\mathrm{SGJ}(\mathrm{pH}$ 3.0). Values shown are means \pm standard deviations $(\mathrm{n}=3)$.
TABLE 2. Viable cell counts of $L$. acidophilus NRRL-B 4495 microencapsulated with different pullulan concentrations under storage at $4^{\circ} \mathrm{C}$ after 4 weeks.

\begin{tabular}{lccc}
\hline WP-pullulan & $\begin{array}{c}\text { Initial cell number } \\
(\log \text { CFU/g) }\end{array}$ & $\begin{array}{c}\text { Survived cell number } \\
(\log \text { CFU/g) }\end{array}$ & Survivial rate (\%) \\
\hline Free bacteria & $9.59 \pm 0.17$ & $5.55 \pm 0.21$ & $57.92 \pm 0.23^{\mathrm{a}}$ \\
WP microcapsule & $9.44 \pm 0.12$ & $7.91 \pm 0.21$ & $81.89 \pm 0.53^{\mathrm{b}}$ \\
$\begin{array}{l}\text { WP/pullulan } \\
\quad \text { microcapsule }\end{array}$ & $9.51 \pm 0.17$ & $7.87 \pm 0.31$ & $82.80 \pm 0.43^{\mathrm{b}}$ \\
\hline
\end{tabular}

${ }^{\mathrm{a}, \mathrm{b}}$ Means \pm standard deviation $(\mathrm{n}=3)$ with different superscript letters in the same column indicate significant differences $(p \leq 0.05)$ among the studied samples.

microcapsules exhibited decreasing cell loss of $1.17 \log$ CFU/g from initial cell count of $9.2 \log \mathrm{CFU} / \mathrm{g}$, while viable counts of WP encapsulated cells decreased about $1.88 \log \mathrm{CFU} / \mathrm{g}$ from initial cell count of $9.44 \log \mathrm{CFU} / \mathrm{g}$. Microencapsulation into $\mathrm{WP} /$ pullulan microcapsules offered protection with survival rate of $87.18 \%$ compared to WP microcapsules possessing a survival rate of $80.04 \%$.

The effect of the bile salt on the cell counts of free and microencapsulated L. acidophilus NRRL B-4485 is presented in Fig. 1B. For free cells, initial viable count of $9.31 \log \mathrm{CFU} / \mathrm{ml}$ was reduced to 7.75 $\log \mathrm{CFU} / \mathrm{ml}$ after $10 \mathrm{~h}$ and were further reduced to $7.10 \log \mathrm{CFU} / \mathrm{ml}$ at the end of incubation. In contrast to free cells, after $10 \mathrm{~h}$ of incubation in bile salt solution, cell counts of WP and WP/pullulan microcapsules decreased to $7.71 \log \mathrm{CFU} / \mathrm{g}$ and $8.52 \log \mathrm{CFU} / \mathrm{g}$ from initial counts of $8.93 \mathrm{log} \mathrm{CFU} / \mathrm{g}$ and $9.27 \log \mathrm{CFU} / \mathrm{g}$, respectively. Beyond $10 \mathrm{~h}$ of incubation, viable cells of encapsulated bacteria showed slight decreases.

This increased survival rates could be attributed by the restricted diffusion of SGJ and bile salts; formation of smoother and denser surface in microcapsules with the presence of pullulan limited the diffusion of harsh gastrointestinal fluids into microcapsules core, leading to protection of encapsulated cells. Moreover, it can be hypothesized that gel network formed in the presence of pullulan also reduced the degradation of whey protein by restricting the diffusion of pepsin (25).

There are various studies conducted to observe the effect of different polymers on probiotic survival when exposed to lethal conditions. Lotfipour et al. (26) incorporated polysaccharide psyllium in alginate to encapsulate probiotic bacteria of $L$. acidophilus DMSZ20079 and concluded that increasing psyllium concentration resulted in an increase in viable cell numbers when microcapsules exposed to simulated gastric acid. Nag et al. (27) combined sodium caseinate with gellan gum for the protection of Lactobacillus casei. Formed microcapsules exhibited $3.1 \mathrm{log}$ reduction when compared to control having $4.6 \mathrm{log}$ reduction in viable cells. On the other hand, incorporation of any polysaccharide into protein wall matrix does not always provide barrier functions. For instance, Guérin et al. (28) incorporated pectin into whey protein wall matrix and used this polymer complex to encapsulate probiotic Bifidobacterium bifidum. After exposure of formed microcapsules to simulated gastrointestinal conditions, they observed a significant reduction in

TABLE 3. Physicochemical characterization of WP/pullulan microcapsules loaded with L. acidophilus NRRL B-4495.

\begin{tabular}{lc}
\hline Physicochemical characteristics & WPI-pullulan microcapsules \\
\hline Moisture content $(\%)$ & $82.36 \pm 0.023$ \\
Water activity $\left(A_{w}\right)$ & $0.95 \pm 0.04$ \\
Color & \\
$\mathrm{L}^{*}$ & $80.29 \pm 0.04$ \\
$\mathrm{a}^{*}$ & $-1.46 \pm 0.01$ \\
$\mathrm{~b}^{*}$ & $1.35 \pm 0.04$ \\
\hline
\end{tabular}

$\mathrm{L}^{*}$ indicates lightness, $\mathrm{a}^{*}$ is the position between green (negative values) and red/ magenta (positive values), and $\mathrm{b}^{*}$ is the position between blue (negative values) and yellow (positive values). 


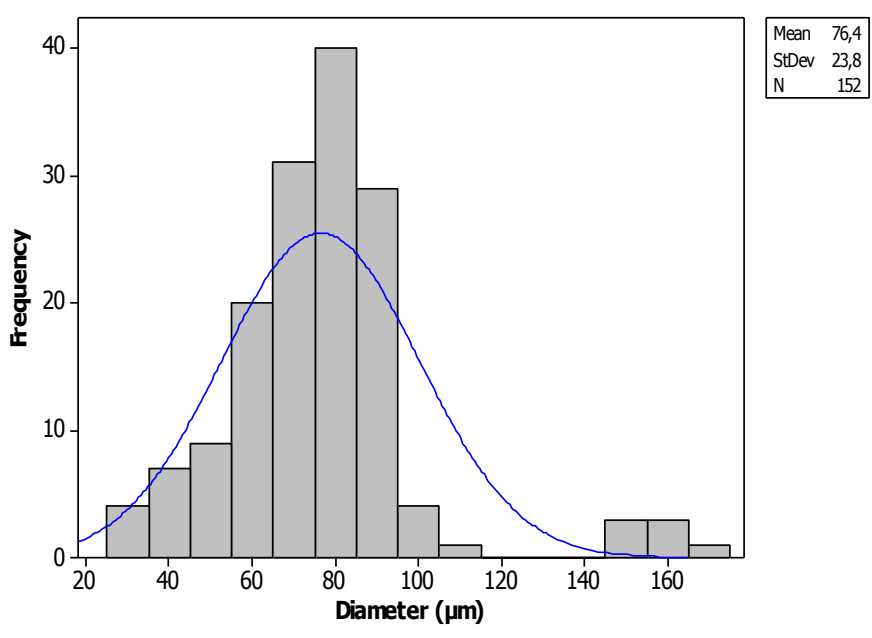

FIG. 3. Frequency distribution of diameters of the WP/pullulan microcapsules.

viable cell numbers. It was explained by using SEM images in details and concluded that having a more porous structure of the microcapsule, easier the penetration of acid and bile facilitates that causes a reduction in the entrapped cell number.

Release into simulated intestinal juice The release characteristic of the developed WP/pullulan microcapsules was investigated since release of viable cells in the intestine is one of the main objectives of microencapsulation. For this assay, microcapsules were first exposed to SGJ at $\mathrm{pH} 3.0$ for $3 \mathrm{~h}$ after which the same microcapsules were transferred into SIJ at pH 8.0 and incubated for further $24 \mathrm{~h}$. The investigated intestinal release characteristic of the encapsulated cells is revealed in Fig. 2. Results indicated that cell counts of released bacteria increased with exposure time. In $1 \mathrm{~h}$ of incubation in SIJ, more than $70 \%$ of encapsulated bacteria were liberated from $\mathrm{WP} /$ pullulan microcapsules, and within $7 \mathrm{~h}$ release of encapsulated cells was completed reaching viable cell numbers of $9.41 \log \mathrm{CFU} / \mathrm{g}$. On the other hand, encapsulated cells in WP microcapsules were calculated to release at the rate of $88.75 \%$ within $1 \mathrm{~h}$ of exposure and after $3 \mathrm{~h}$ exposure in SIJ, release of all encapsulated bacteria appeared to occur with $9.11 \log \mathrm{CFU} / \mathrm{g}$ viable cells at the end of $3 \mathrm{~h}$ of exposure to SIJ. Pullulan is a slowly digested carbohydrate by human gastrointestinal enzymes $(25,29)$. This behavior of pullulan to intestinal enzymes should have stabilized the gel characteristics of WP/pullulan microcapsules in the intestine after exposure to SGJ and bile. Moreover, larger pore sized microcapsules were obtained by pullulan that was expected to limit the diffusion of SIJ solution. Since, large diameter size capsules have a lower surface area-tovolume ratio, thus these capsules usually would not undergo the same rate of capsule matrix degradation as the smaller-sized ones causing more prolonged release profile $(30,31)$.

Storage stability To evaluate the efficiency of addition of pullulan into microencapsulation wall material under refrigerated storage, free cells and WP/pullulan microcapsules were stored for 4 weeks. It was clear that microencapsulation of probiotic bacteria cells led to a higher survival compared to free bacteria cells under same conditions (Table 2). For free bacteria, gradual decrease in viable cell numbers thus low survival rate was observed. Initial cell counts of $9.59 \log \mathrm{CFU} / \mathrm{ml}$ decreased to $5.55 \log \mathrm{CFU} / \mathrm{ml}$ for free cells after 4 weeks of storage, while microencapsulation into $\mathrm{WP} /$ pullulan microcapsules afforded a decrease of viable cell numbers from $9.51 \mathrm{log} \mathrm{CFU} / \mathrm{g}$ to $7.87 \mathrm{log} \mathrm{CFU} / \mathrm{g}$ after 30 days of
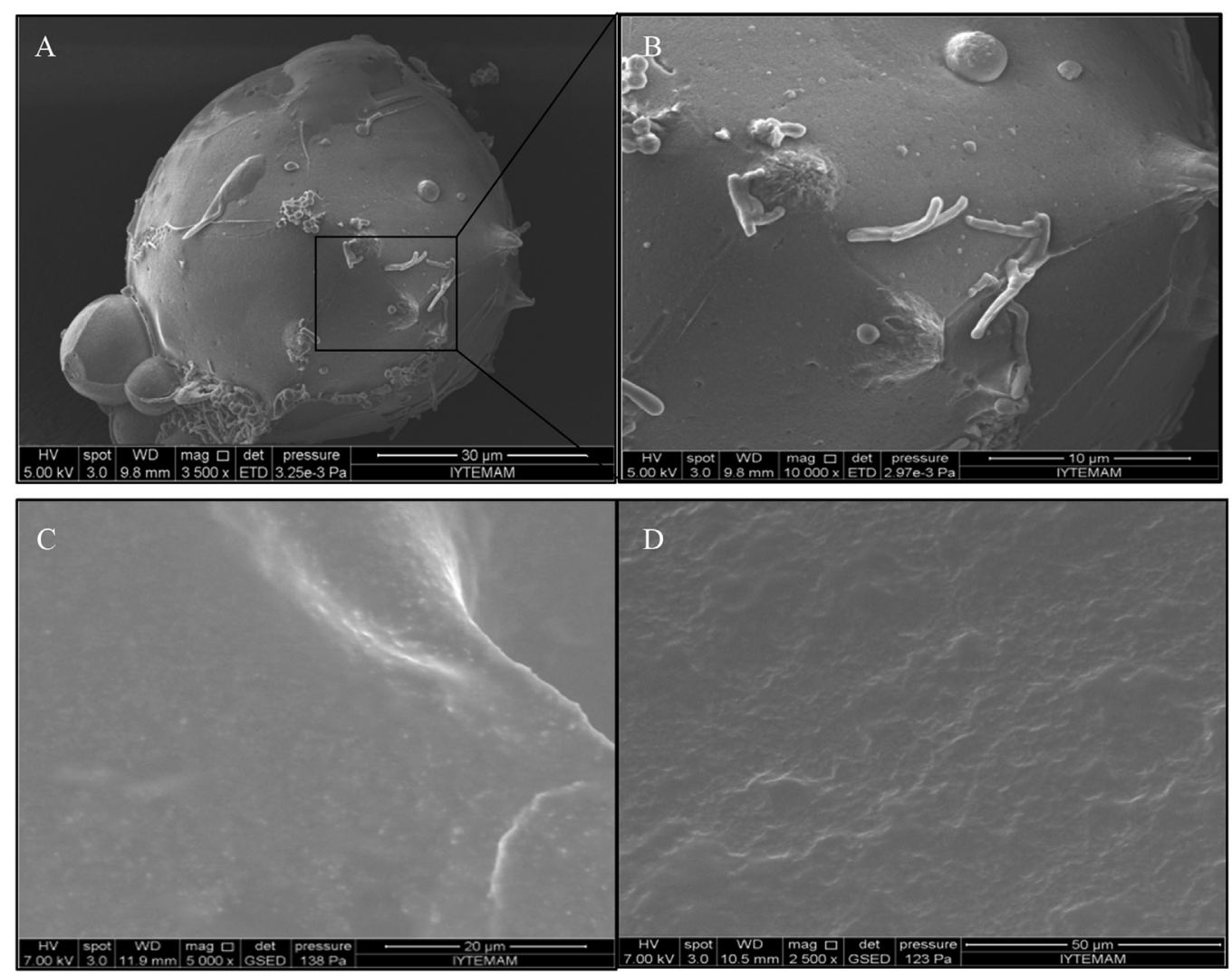

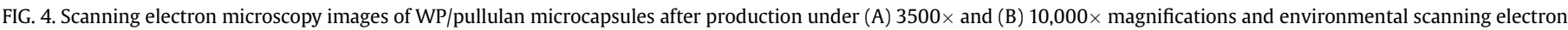
microscopy image of a surface (C) and cross-section (D) of WP/pullulan microcapsules. Scale bars represent 30, 10, 20 and $50 \mu \mathrm{m}$, respectively. 
storage at $4^{\circ} \mathrm{C}$. Moreover, after 30 days of storage, probiotic cells survived above desired therapeutic level (7 log CFU/g capsule). On the other hand, no significant difference $(p>0.05)$ was calculated between survival rates of WP and WP/pullulan microcapsules. In contrast to our observation, various reports exposing positive effects of polysaccharide incorporation to capsule wall materials exist in the literature. Oliveira et al. (32) used complex coacervation followed by the spouted-bed-drying method for microencapsulation of L. acidophilus (LAC 4) in casein/ pectin polymer complex. After storage for 30 days, no significant decrease in cell numbers was calculated; viable cells decreased from $9.16 \log \mathrm{CFU} / \mathrm{g}$ to $8.92 \log \mathrm{CFU} / \mathrm{g}$. In another study, LópezRubio et al. (33) used electrospinning technique to encapsulate Bifidobacterium strains in a protein (whey protein concentrate) and a carbohydrate (pullulan). After 120 days of storage, pullulan microcapsules exposed a significant drop of 4.0 log units $(p<0.001)$ in viable cells of $B$. animalis Bb12 when compared to WPI encapsulated cells having decrease of 2 log units.

Physicochemical characterization of microcapsules Color values of the formed microcapsules in Table 3 reveal that these microcapsules have white color and can be applied dairy based food such as yogurt, cheese and whey based drinks. However, the color of the formed microcapsules may undergo some color changes when added to different food groups and this may be another topic of further research.

The moisture content and water activity $\left(A_{w}\right)$ of the microcapsules was found to be $82.36 \%$ and 0.95 , respectively (Table 3 ). Moisture content and water activity affect the stabilities of the microcapsules throughout storage; higher moisture contents and water activities have been noted to increase oxygen permeability of wall materials and cause higher decline in surviving viable numbers of microorganisms during storage (34). Furthermore, low moisture content and water activity values in microcapsules contribute to improve physical and bulk properties (35). In this work, WP/pullulan microcapsules exhibited high water activity and moisture content values that can create some problems for use in some food products for long time storage. For this reason, for the possible prolonged storage of encapsulated bacteria in functional foods, it was necessary to study the effect of drying to reduce the moisture content for practical uses.

Microcapsule size is an important parameter that both reflect the quality of added food product and protection of cells during gastrointestinal transit. In industrial production, low capsule sizes are required since high capsule sizes above $100 \mu \mathrm{m}$ create sandy and gritty undesirable textural property in the food product in which they are used $(36,37)$. In this study, incorporation of pullulan was expected to create large particle sizes since by the increase in polymer concentration, the viscosity of the inner phase of the primary emulsion was increased, causing resistance to break into smaller droplets and resulted in larger capsule size $(21,22)$. Fig. 3 shows the frequency of diameter distribution of developed WP/ pullulan microcapsules and results revealed that microcapsules obtained in this work had an average mean diameter of $76.40 \mu \mathrm{m}$ and diameter distributions were between 30 and $172 \mu \mathrm{m}$. Besides large particle sizes above $100 \mu \mathrm{m}$, highest frequencies for the microcapsules were obtained between 55 and $95 \mu \mathrm{m}$. Moreover the frequency distribution of large sized microcapsules was lower than 10 and is skewed more towards the smaller diameter values side relative to the most frequently occurring value. In literature (8), with small microcapsules as capsule sizes surface area to volume increases can further lead to reduced survival during gastrointestinal transit; smaller diameter in microcapsules generally results in decreased microencapsulation efficiency and protection against harsh conditions. As a result frequency distribution of microcapsules represents that by emulsification/cold gelation method, with
$\mathrm{WP} /$ pullulan polymer blend formed microcapsules showed ideal size for food applications. Different attempts were made in order to encapsulate probiotic microorganism to provide survival during gastrointestinal storage in effective ways and microcapsules with varying mean diameters were obtained. For instance, Wang et al. (30) used chickpea protein incorporated with $\kappa$-carrageenan/alginate to encapsulate Bifidobacterium adolescentis (ATCC 15703) cells using the emulsion technique. In the study, the presence of $\kappa$ carrageenan created larger particle sizes of about $838.5 \mu \mathrm{m}$ when
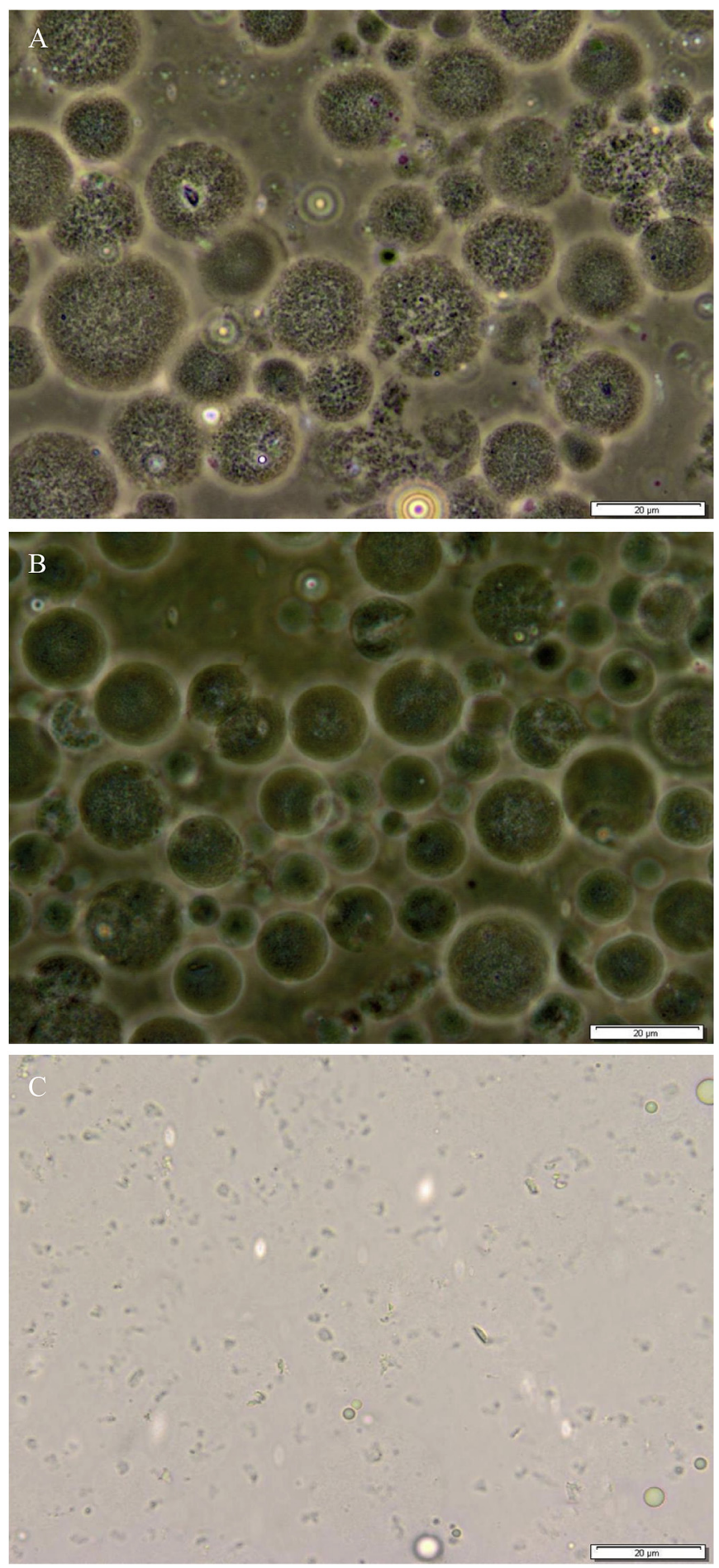

FIG. 5. Optical microscopy images of WP/pullulan microcapsules after (A) SGJ, (B) bile salt and (C) SIJ exposure at $100 \times$ magnifications. Scale bars represent $20 \mu \mathrm{m}$. 
compared to alginate having $22 \mu \mathrm{m}$ mean diameters. In another study using emulsion technique conducted by Heidebach et al. (38), probiotic Lactobacillus paracasei ssp. paracasei F19 and B. lactis Bb12 cells were encapsulated via transglutaminase-catalysed gelation of casein and microcapsules having a mean diameter of $165 \mu \mathrm{m}$ were obtained.

Microcapsule morphology Morphological structure and shape of microcapsules are illustrated by scanning electron microscopy (SEM) and environmental scanning electron microscopy (ESEM) (Fig. 4). It is observed in Fig. 4A that the formed microcapsules are spherical in shape with a smooth and homogeneous surface having small pores. From the images, it was confirmed that probiotic L. acidophilus NRRL B-4495 cells were effectively encapsulated and encapsulated cells are visible on the external surface of the microcapsules in Fig. 4B. The morphology from ESEM images (Fig. 4C,D) indicates that compact, homogeneous and smooth structure throughout the microcapsule was observed due to film forming characteristics of pullulan thus providing better barrier properties to stop diffusion of acid and bile and release of encapsulated bacteria when compared to whey protein microcapsules. Similar results were noted by López-Rubio et al. (33) using electrospinning technique. On the other hand, according to the investigation conducted by Gounga et al. (14), incorporation of pullulan in whey protein created pinholes on the surface of probiotic edible films. Therefore, protein-pullulan interactions need to be investigated.

Stability of formed WP/pullulan microspheres during exposure to simulated gastrointestinal conditions was visualized under light microscopy. From the appearances of eroded surfaces in Fig. 5, it can be considered that WP/pullulan microcapsules were partially destroyed due to pepsin action and cracks on surface of polymer layer were less observed in bile exposed ones. It may be due to limited penetration of artificial gastric solutions into the core was limited supporting the maintenance of spherical shape and viable cell numbers above required levels. Light microscopy image after sequential exposure in SIJ provides information that after $24 \mathrm{~h} \mathrm{WP} /$ pullulan microcapsules were completely degraded and enabling the release of encapsulated cells. In conclusion, the diffusion of SIJ increased and encapsulated bacteria released in high numbers in a short time. Similar to our results, effective disintegration of microcapsules under simulated gastrointestinal conditions and release of encapsulated cells have been previously reported (39-41).

\section{ACKNOWLEDGMENTS}

This research was carried out with the financial support of the Izmir Institute of Technology, Ýzmir, Turkey (2011IYTE12). The authors thank for the material support received from Ingredients Hayashibara Shoji, Inc. (Okayama, Japan), Kale Kimya Group (Kocaeli, İzmir) and Danisco (Grindsted, Denmark). The authors also thank the Materials Research Center and Biotechnology and Bioengineering Research and Applications Center in Izmir Institute of Technology for the generous use of their facilities.

\section{References}

1. Champagne, C. P., Gardner, N. J., and Roy, D.: Challenges in the addition of probiotic cultures to foods, Crit. Rev. Food Sci., 45, 61-84 (2005).

2. Krasaekoopt, W., Bhandari, B., and Deeth, H.: Evaluation of encapsulation techniques of probiotics for yoghurt, Int. Dairy J., 13, 3-13 (2003).

3. Anal, A. K. and Singh, H.: Recent advances in microencapsulation of probiotics for industrial applications and targeted delivery, Trends Food Sci. Technol., 18, 240-251 (2007).

4. Rathore, S., Desai, P. M., Liew, C. V., Chan, L. W., and Heng, P. W. S.: Microencapsulation of microbial cells, J. Food Eng., 116, 369-381 (2013).

5. Duongthingoc, D., George, P., Gorczyca, E., and Kasapis, S.: Studies on the viability of Saccharomyces boulardii within microcapsules in relation to the thermomechanical properties of whey protein, Food Hydrocoll., 42, 232-238 (2014).

6. Martin-Dejardin, F., Ebel, B., Lemetais, G., Nguyen Thi Minh, H., Gervais, P., Cachon, R., and Chambin, 0.: A way to follow the viability of encapsulated Bifidobacterium bifidum subjected to a freeze-drying process in order to target the colon: interest of flow cytometry, Eur. J. Pharm. Sci., 49, 166-174 (2013).

7. Song, H., Yu, W., Gao, M., Liu, X., and Ma, X.: Microencapsulated probiotics using emulsification technique coupled with internal or external gelation process, Carbohydr. Polym., 96, 181-189 (2013).

8. Sultana, K., Godward, G., Reynolds, N., Arumugaswamy, R., Peiris, P., and Kailasapathy, K.: Encapsulation of probiotic bacteria with alginate-starch and evaluation of survival in simulated gastrointestinal conditions and in yoghurt, Int. J. Food Microbiol., 62, 47-55 (2000).

9. Picot, A. and Lacroix, C.: Encapsulation of Bifidobacteria in whey protein-based microcapsules and survival in simulated gastrointestinal conditions and in yoghurt, Int. Dairy J., 14, 505-515 (2004).

10. Ying, D., Schwander, S., Weerakkody, R., Sanguansri, L., GantenbeinDemarchi, C., and Augustin, M. A.: Microencapsulated Lactobacillus rhamnosus GG in whey protein and resistant starch matrices: probiotic survival in fruit juice, J. Funct. Foods, 5, 98-105 (2013).

11. Barnett, C., Smith, A., Scanlon, B., and Israilides, C. J.: Pullulan production by Aureobasidium pullulans growing on hydrolysed potato starch waste, Carbohydr. Polym., 38, 203-209 (1999).

12. Singh, R. S., Saini, G. K., and Kennedy, J. F.: Pullulan: microbial sources, production and applications, Carbohydr. Polym., 73, 515-531 (2008).

13. Gounga, M. E., Xu, S. Y., Wang, Z., and Yang, W. G.: Effect of whey protein isolate-pullulan edible coatings on the quality and shelf life of freshly roasted and freeze-dried chinese chestnut, J. Food Sci., 73, 155-161 (2008).

14. Gounga, M. E., Xu, S.-Y., and Wang, Z.: Whey protein isolate-based edible films as affected by protein concentration, glycerol ratio and pullulan addition in film formation, J. Food. Eng., 83, 521-530 (2007).

15. Wood, K. A.: Synbiot production and encapsulation (M. Sc. thesis). University of Saskatchewan, Saskatoon, SK (2010).

16. Chen, L. and Subirade, M.: Effect of preparation conditions on the nutrient release properties of alginate-whey protein granular microspheres, Eur. J. Pharm. Biopharm., 65, 354-362 (2007).

17. Guo, Z., Wang, J. C., Yan, L. Y., Chen, W., Liu, X. M., and Zhang, H. P.: In vitro comparison of probiotic properties of Lactobacillus casei Zhang, a potential new probiotic, with selected probiotic strains, Lwt-Food Sci. Technol., 42, 1640-1646 (2009).

18. Bao, Y., Zhang, Y. C., Zhang, Y., Liu, Y., Wang, S. Q., Dong, X. M., Wang, Y. Y., and Zhang, H. P.: Screening of potential probiotic properties of Lactobacillus fermentum isolated from traditional dairy products, Food Control, 21, 695-701 (2010).

19. Dianawati, D., Mishra, V., and Shah, N. P.: Role of calcium alginate and mannitol in protecting Bifidobacterium, Appl. Environ. Microbiol., 78, 6914-6921 (2012).

20. Rajam, R., Karthik, P., Parthasarathi, S., Joseph, G. S., and Anandharamakrishnan, C.: Effect of whey protein-alginate wall systems on survival of microencapsulated Lactobacillus plantarum in simulated gastrointestinal conditions, J. Funct. Foods, 4, 891-898 (2012).

21. Lokhande, A. B., Deshmukh, T. A., and Patil, V. R.: Evaluation of repaglinide encapsulated nanoparticles prepared by sonication method, Int. J. Pharm. Pharm. Sci., 5, 517-520 (2013).

22. Biswal, I., Dinda, A., Das, D., Si, S., and Chowdary, K. A.: Encapsulation protocol for highly hydrophilic drug using non biodegradable polymer, Int. J. Pharm. Pharm. Sci., 3, 256-259 (2011).

23. Sandoval-Castilla, O., Lobato-Calleros, C., Garcia-Galindo, H. S., AlvarezRamirez, J., and Vernon-Carter, E. J.: Textural properties of alginate-pectin beads and survivability of entrapped $L$. casei in simulated gastrointestinal conditions and in yoghurt, Food Res. Int., 43, 111-117 (2010).

24. Lee, K. Y. and Heo, T. R.: Survival of Bifidobacterium longum immobilized in calcium alginate beads in simulated gastric juices and bile salt solution, Appl. Environ. Microbiol., 66, 869-873 (2000).

25. Wolf, B. W., Garleb, K. A., Choe, Y. S., Humphrey, P. M., and Maki, K. C.: Pullulan is a slowly digested carbohydrate in humans, J. Nutr., 133, 1051-1055 (2003).

26. Lotfipour, F., Mirzaeei, S., and Maghsoodi, M.: Preparation and characterization of alginate and psyllium beads containing Lactobacillus acidophilus, Sci. World J., 2012 (2012).

27. Nag, A., Han, K.-S., and Singh, H.: Microencapsulation of probiotic bacteria using $\mathrm{pH}$-induced gelation of sodium caseinate and gellan gum, Int. Dairy J., 21, 247-253 (2011).

28. Guérin, D., Vuillemard, J.-C., and Subirade, M.: Protection of Bifidobacteria encapsulated in polysaccharide-protein gel beads against gastric juice and bile, J. Food Prot., 66, 2076-2084 (2003).

29. Peters, H. P. F., Ravestein, P., van der Hijden, H. T. W. M., Boers, H. M., and Mela, D. J.: Effect of carbohydrate digestibility on appetite and its relationship to postprandial blood glucose and insulin levels, Eur. J. Clin. Nutr., 65, 47-54 (2011). 
30. Wang, J., Korber, D. R., Low, N. H., and Nickerson, M. T.: Entrapment, survival and release of Bifidobacterium adolescentis within chickpea protein-based microcapsules, Food. Res. Int., 55, 20-27 (2014).

31. Klemmer, K. J., Korber, D. R., Low, N. H., and Nickerson, M. T.: Pea proteinbased capsules for probiotic and prebiotic delivery, Int. J. Food Sci. Technol., 46, 2248-2256 (2011).

32. Oliveira, A. C., Moretti, T. S., Boschini, C., Baliero, J. C. C., Freitas, O., and Favaro-Trindade, C. S.: Stability of microencapsulated B. lactis (Bl 01) and L. acidophilus (LAC 4) by complex coacervation followed by spray drying, J. Microencapsul., 24, 685-693 (2007).

33. López-Rubio, A., Sanchez, E., Wilkanowicz, S., Sanz, Y., and Lagaron, J. M.: Electrospinning as a useful technique for the encapsulation of living Bifidobacteria in food hydrocolloids, Food Hydrocoll., 28, 159-167 (2012).

34. Clementi, F. and Rossi, J.: Effect of drying and storage conditions on survival of Leuconostoc oenos, Am. J. Enol. Vitic., 35, 183-186 (1984).

35. Onwulata, C., Smith, P., and Holsinger, V.: Flow and compaction of spraydried powders of anhydrous butteroil and high melting milkfat encapsulated in disaccharides, J. Food Sci., 60, 836-840 (1995).

36. Vivek, K.: Use of encapsulated probiotics in dairy based foods, Int. J. Food Agri. Vet. Sci., 3, 188-199 (2013).
37. Annan, N. T., Borza, A. D., and Hansen, L. T.: Encapsulation in alginate-coated gelatin microspheres improves survival of the probiotic Bifidobacterium adolescentis 15703T during exposure to simulated gastro-intestinal conditions Food Res. Int., 41, 184-193 (2008)

38. Heidebach, T., Först, P., and Kulozilk, U.: Transglutaminase-induced caseinate gelation for the microencapsulation of probiotic cells, Int. Dairy J., 19, 77-84 (2009).

39. Gebara, C., Chaves, K. S., Ribeiro, M. C. E., Souza, F. N., Grosso, C. R. F., and Gigante, M. L.: Viability of Lactobacillus acidophilus La5 in pectin-whey protein microparticles during exposure to simulated gastrointestinal conditions, Food Res. Int., 51, 872-878 (2013).

40. Gbassi, G. K., Vandamme, T., Yolou, F. S., and Marchioni, E.: In vitro effects of $\mathrm{pH}$, bile salts and enzymes on the release and viability of encapsulated Lactobacillus plantarum strains in a gastrointestinal tract model, Int. Dairy J., 21, 97-102 (2011).

41. Burgain, J., Gaiani, C., Cailliez-Grimal, C., Jeandel, C., and Scher, J.: Encapsulation of Lactobacillus rhamnosus GG in microparticles: influence of casein to whey protein ratio on bacterial survival during digestion, Innov. Food Sci. Emerg. Technol., 19, 233-242 (2013). 